\title{
Indoor radon: An overview on a perennial problem
}

\author{
F. Pacheco-Torgal ${ }^{*}$ \\ C-TAC Research Unit, University of Minho, 4800-058 Guimarães, Portugal
}

\section{A R T I C L E I N F O}

\section{Article history:}

Received 21 June 2012

Received in revised form

29 July 2012

Accepted 2 August 2012

\section{Keywords:}

Radon

Energy efficiency building refurbishment

Radon-proof membrane

Soil depressurization

\begin{abstract}
A B S T R A C T
According to the World Health Organization (WHO) radon constitutes the second cause of lung cancer in the general population, the first being smoking. In addition health investigations also show that children are more susceptible than adults to ionizing radiation. In the past, it was accepted that only radon concentrations above $400 \mathrm{~Bq} / \mathrm{m}^{3}$ could constitute a health risk, however, recent epidemiological findings demonstrate lung cancer risk from exposure to indoor radon at levels in the order of $100 \mathrm{~Bq} / \mathrm{m}^{3}$. Furthermore, lung cancer aggravates based on the accumulated inhaled dose and, according to WHO, there is no lower radon level below which the risk from exposure disappears. Nevertheless, some surveys show that the majority of the public seems to consider the health risks involved in radon exposure as being negligible. To make things worse, only a few countries require the use of protection measures for buildings located in radon affected areas. This paper reviews literature on radon as a source of indoor air contamination. It covers recent legislation, building protecting measures and their cost-effectiveness. It also covers the case of radon emissions from construction and decorative materials.
\end{abstract}

(c) 2012 Elsevier Ltd. All rights reserved.

\section{Introduction}

Radon $\left({ }^{222} \mathrm{Rn}\right)$ is a colourless, odourless, tasteless radioactive gas that comes from the ground in granitic or shale related areas but it's source can also be from granite floor materials or even from construction materials thus polluting indoor air [1]. Radon was identified as a human lung carcinogen in 1986 by the WHO [2]. According to this organization "radon gas is by far the most important source of ionizing radiation among those that are of natural origin". This gas constitutes the second cause of death after lung cancer [3]. Evidence between indoor radon exposure and lung cancer was reported by Field et al. two decades ago [4]. "Most radon gas inhaled is immediately exhaled, however, if decay occurs in the lungs, the resulting solid radioactive particles can settle onto bronchial epithelial cells causing DNA damage" [5]. Recent investigations carried out in Portugal show that of the 8514 lung cancer deaths observed, from $18 \%$ to $28 \%$ could be associated with indoor radon exposure [6]. Children are considered a risk group in terms of radon since association between residential radon and acute leukaemia risk was reported [7]. Synergic effects between smoking and radon, in lung cancer, have also been reported [8]. However, other authors [9] state that the possibility of radon having a causative effect on other cancers has been explored but not yet proven. A possible correlation between radon and skin cancer was suggested by others

\footnotetext{
* Tel.: +351 253 510200; fax: +351253510213.

E-mail addresses: f.pachecotorgal@gmail.com, torgal@civil.uminho.pt.
}

[10]. In the past, it was commonly accepted that only radon concentrations above $400 \mathrm{~Bq} / \mathrm{m}^{3}$ could be a source of concern, however, recent investigations show that this threshold is far from being safe. Dinua et al. [11] studied 90 households in Spain with a maximum radon concentration of $366 \mathrm{~Bq} / \mathrm{m}^{3}$, stating that an excessive number of cancer related deaths occurred in that area. Other studies [12] show health related risks even for radon concentrations below $200 \mathrm{~Bq} / \mathrm{m}^{3}$. This is the radon concentration at which action is currently advocated for in many countries. Recent epidemiological findings from residential studies, however, demonstrate lung cancer risk can arise from exposure to indoor radon at levels of the order of $100 \mathrm{~Bq} / \mathrm{m}^{3}$ [13]. According to WHO, the lung cancer risk increases linearly with long term radon exposure, with no evidence for a threshold [3]. Extensive largescale surveys of indoor radon in Norway show that $9 \%$ of the present housing stock (approximately 175,000 dwellings), has an annual average radon concentration exceeding the Norwegian action level of $200 \mathrm{~Bq} / \mathrm{m}^{3}$. Also, it states that 30,000 Norwegians live in dwellings where the average radon concentration is higher than $1000 \mathrm{~Bq} / \mathrm{m}^{3}$ [14]. Nevertheless, some surveys show that the majority of the public seems to consider the health risks involved from exposure to radon as being negligible. Bradley et al. [15] found that only $10 \%$ of those with a raised level of radon took any steps to remediate this problem. Other authors [16] discovered that even when householders knew of the existence of raised radon levels in their dwellings, they rarely remediated. Despite numerous awareness campaigns, limited numbers of householders have tested their 
homes and only a minority of the affected householders have remediated the problem [17]. Moreover, a recent survey shows a wide range of the public perception on radon risk not significantly influenced by public health campaigns [18].The building sector is the largest energy user and $\mathrm{CO}_{2}$ emitter in the European Union (EU) and is responsible for about $40 \%$ of the EU's total final energy consumption and $\mathrm{CO}_{2}$ emissions. The European Energy Performance of Buildings Directive 2002/91/EC (EPBD) [19] has been recast in the form of the 2010/31/EU [20] of the European Parliament. One of the new aspects of the 2010/31/EU is the introduction of the concept of nearly zero-energy building. The article 9 of the European Directive establishes that, by the 31st of December of 2020, all new constructions have to be nearly zero-energy buildings. However, new buildings have limited impacts on overall energy reduction as they represent just a tiny fraction of the existent building stock. Existing buildings constitute, therefore, the greatest opportunity for energy efficiency improvements [21]. Besides, new homes use four to eight times more resources than an equivalent refurbishment [22], which constitutes an extra argument in favour of building refurbishment. The energy efficiency building refurbishment context constitutes, consequently, a great opportunity to emphasize and try to solve the radon problem.

\section{Regulation on indoor radon}

Reference level represents the maximum accepted average annual radon concentration in a residential dwelling. When radon measurements indicate that this level has been exceeded, it is strongly recommended that action is taken to reduce the radon concentration [23].The concept of reference level differs from that of action level. The latter was used in most countries prior to the most recent recommendations of the International Commission on Radiological Protection-ICRP [24]. In the UK, the National Radiological Protection Board identified, in 1990, an action level of $200 \mathrm{~Bq} / \mathrm{m}^{3}$. Additionally, when more than $1 \%$ of domestic properties in an area of the UK are above the action level, the area is designated as a radon "affected area" in which regulatory and promotional measures are adopted [25]. A WHO survey of 36 countries found that almost all of them have set reference levels for existing housing of between $200 \mathrm{~Bq} / \mathrm{m}^{3}$ and $400 \mathrm{~Bq} / \mathrm{m}^{3}$. Some countries have set different reference levels for new and existing buildings, with lower values for new houses [3]. WHO proposes a reference level of $100 \mathrm{~Bq} / \mathrm{m}^{3}$ to minimize health hazards due to indoor radon exposure. However, if this level cannot be reached under the prevailing country-specific conditions, the chosen reference level should not exceed $300 \mathrm{~Bq} / \mathrm{m}^{3}$. Table 1 shows how different international organizations recommend very different indoor radon concentration thresholds. However, one thing they have in common, recent and forthcoming thresholds are much lower than the previous ones. Table 2 presents the different action levels and target levels currently used situation in several European countries as well as the status of the radon situation in those countries. The data reveals that only Germany and Norway have conservative action and target levels $\left(100 \mathrm{~Bq} / \mathrm{m}^{3}\right)$ which are in line with the threshold recommend by the WHO. In the remaining

Table 1

Summary of indoor radon concentration thresholds $\left(\mathrm{Bq} / \mathrm{m}^{3}\right)$ [26].

\begin{tabular}{llllll}
\hline \multirow{2}{*}{ Organisation } & \multicolumn{2}{l}{ Previous/current } & & \multicolumn{2}{l}{ Recent/forthcoming } \\
\cline { 2 - 3 } \cline { 5 - 6 } \cline { 5 - 6 } & Dwellings & Workplaces & & Dwellings & Workplaces \\
\hline ICRP & $\leq 600$ & $\leq 1500$ & & $\leq 300$ & \\
WHO & 250 & & & 100 & \\
EU & 400 & $\leq 1000$ & & $\leq 300$ & $\leq 1000$ \\
\hline
\end{tabular}

countries two different situations can be identified, the case of Italy, Ireland and UK that have an action and target levels $\left(200 \mathrm{~Bq} / \mathrm{m}^{3}\right)$ below the ICRP threshold and the countries which still have the threshold of $200 \mathrm{~Bq} / \mathrm{m}^{3}$ as action level or both, like it happens in Switzerland and Portugal.

\section{Protection measures}

In the UK new properties must be fitted with a sump if more than $10 \%$ of the existing properties in an area show readings above the action level. A fan can then be added if subsequent tests reveal that one is needed to further reduce radon levels. Regulations now require that a radon-proof membrane designed to prevent radon entering a property should be installed in new houses built in areas of the UK where $3 \%$ or more of existing properties are above the action level [28]. Recent recommendations emphasize that all new homes in England and Wales, regardless of location, be built with radon-proof membranes [29]. The WHO Handbook [1] summarizes the protection measures as follows:

(a) Active soil depressurization

(b) Passive soil depressurization

(c) Sealing of surfaces

(d) Barriers and membranes

(e) Ventilation of unoccupied spaces

(f) Ventilation of occupied spaces.

Analyses of different measures show that active sub-slab depressurization systems usually are the most effective preventive measure as a stand-alone solution, assuming an airtight construction [14]. Several studies [30,31] have already demonstrated that radon-proof membranes have a significant failure rate. This leads to new homes in which radon levels are above the action level. Therefore, it is important to ensure satisfactory airtightness in the radon barrier towards the building ground, e.g. by avoiding perforations and ensuring sufficient airtightness in joints and feedthroughs. Different authors address several design details concerning protection measures to reduce indoor radon concentration. Fig. 1 shows details for the protection of a suspended concrete floor, and also, of a ground bearing concrete floor slab. Arvela [33] gives details on the use of bitumen felt and elastic sealants to achieve airtightness (Fig. 2a) and also the installation of a perforated pipe to reduce radon pressure (Fig. $2 \mathrm{~b}$ ). Those authors compared the effectiveness of different protection measures in order to reduce indoor radon concentration (Table 3). They stated that sub-slab piping with an operating fan provides an efficient preventive measure. They also mentioned that in $80 \%$ of houses with a sub-slab piping connected to an operating fan, radon concentration was below the action level of $200 \mathrm{~Bq} / \mathrm{m}^{3}$. In houses with piping but no fan, however, the corresponding fraction was only $45 \%$. The corresponding median values of radon concentration in these houses were 55 and $220 \mathrm{~Bq} / \mathrm{m}^{3}$, respectively. They also mentioned that sub-slab piping without a fan had no remarkable effect on radon concentration. Other authors [34] report the development of a new construction for an airtight joint between the foundation wall and the floor slab. In the new sealing practice, bitumen felt will be installed underneath the floor slab in direct contact with the concrete slab (Fig. 3). Those authors also mention that a group of houses with this new measure located in areas with radon concentration exceeding $200 \mathrm{~B} / \mathrm{qm}^{3}$, show low indoor radon concentrations (20-60 Bq/ $\left./ \mathrm{m}^{3}\right)$. Groves-Kirkby et al. [35] mentioned that post-construction remediation using conventional fan-assisted sump technology proved to be extremely effective in reducing radon concentrations while the use of radon-barrier membranes installed during construction do not consistently provide adequate 
Table 2

Status of radon situation in several European countries [27].

\begin{tabular}{|c|c|c|c|c|c|}
\hline \multirow[t]{2}{*}{ Country } & \multirow{2}{*}{$\begin{array}{l}\text { Action level for remediation } \\
\left(\mathrm{Bq} / \mathrm{m}^{3}\right)\end{array}$} & \multirow{2}{*}{$\begin{array}{l}\text { Target level for prevention } \\
\left(\mathrm{Bq} / \mathrm{m}^{3}\right)\end{array}$} & \multicolumn{3}{|l|}{ Status of remediation } \\
\hline & & & Estimated number of dwellings & Exceeding the action level & Already remediated \\
\hline Austria & 400 & 200 & $3,700,000$ & $89,000(2.4 \%)$ & $25(0 \%)$ \\
\hline Belgium & 400 & 200 & $5,043,000$ & $20,000(0.4 \%)$ & $1000(5 \%)$ \\
\hline Czech Republic & 400 & 200 & $3,900,000$ & $76,000(1.9 \%)$ & $4000(5.3 \%)$ \\
\hline Finland & 400 & 200 & $2,450,000$ & $59,000(2.4 \%)$ & $4500(7.6 \%)$ \\
\hline France & 400 & - & $32,756,000$ & $968,500(3 \%)$ & - \\
\hline Germany & 100 & 100 & $39,900,000$ & $1,930,000(4.8 \%)$ & $1000(0.1 \%)$ \\
\hline Greece & 400 & 200 & $5,627,000$ & - & - \\
\hline Ireland & 200 & 200 & $1,934,000$ & $91,000(4.7 \%)$ & - \\
\hline Italy & 200 & 200 & $22,000,000$ & $902,000(4.1 \%)$ & $500(0.1 \%)$ \\
\hline Norway & 100 & 100 & $2,274,000$ & $42,700(18.8 \%)$ & - \\
\hline Portugal & 400 & 400 & - & $2.6 \%$ & - \\
\hline Spain & - & - & - & - & - \\
\hline Switzerland & 400 & 400 & $4,000,000$ & $75,000(1.9 \%)$ & $500(0.7 \%)$ \\
\hline UK & 200 & 200 & $23,000,000$ & $100,000(0.4 \%)$ & $15,000(15 \%)$ \\
\hline
\end{tabular}

radon protection, specifically failing to reduce the internal radon to concentrations below the action level of $200 \mathrm{~Bq} / \mathrm{m}^{3}$. The use of soil depressurisation systems (SDS) is very effective in reducing radon concentrations although the passive SDS (Fig. 4) is much more costeffective than mechanical SDS [36].

\section{Cost-effectiveness analyses}

Coskeran et al. [37] used the Garber-Phelps criterion to determine the percentage of householders that must remediate, in a particular area, in order to the radon remediation program to be

a
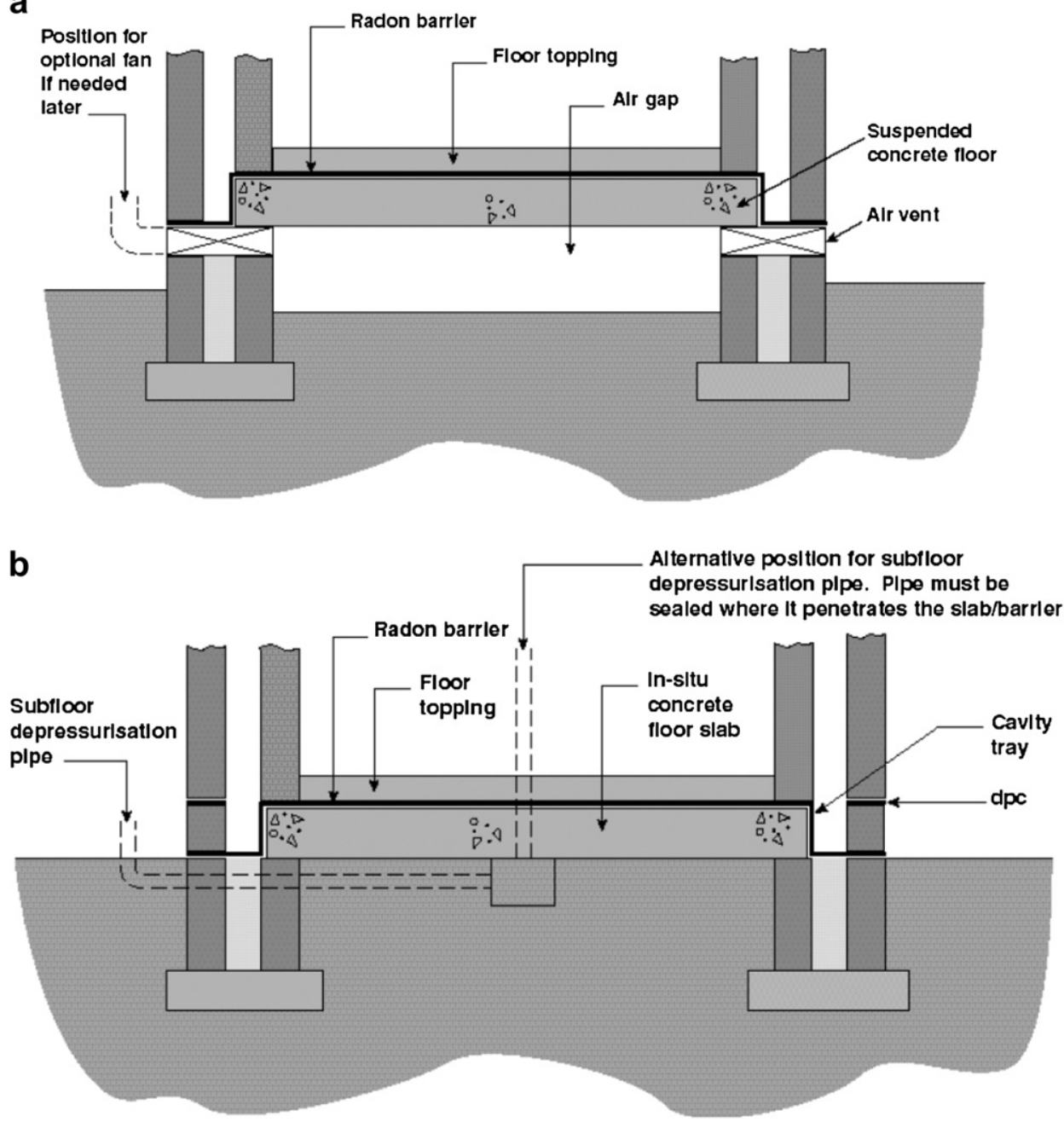

Fig. 1. Radon protection: (a) to a suspended concrete floor; (b) to a ground bearing concrete floor slab [32]. 
a
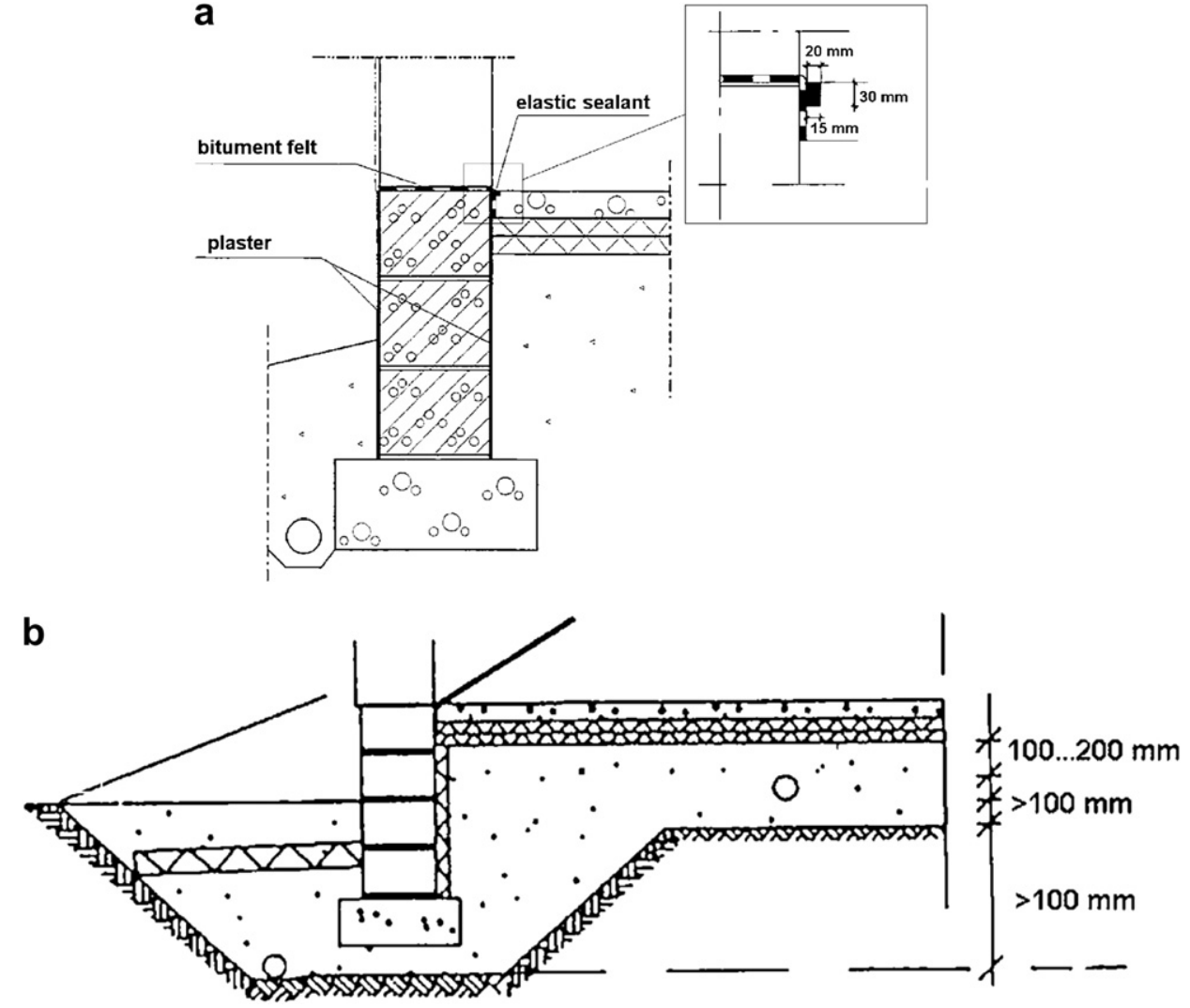

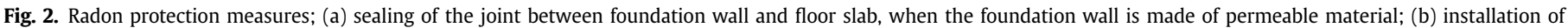
a suction pipe in the gravel layer [33].

cost-effective. This criterion states that health programs should be considered cost-effective, for policy purposes, if the cost per life year gained is less than the double of the average income [38]. These authors state that radon remediation programs will only produce large health gains, and be justified on cost grounds, if a higher percentage of householders takes action. They also state that the percentage of properties above the action level is a significant determinant of whether or not a program will produce costeffective health outcomes in an area. Other authors [39] show that, for areas with a low percentage of homes with radon concentration above action level, the more cost-effective course of actions is as follows:

(1) construct new homes without protection against radon;

\section{Table 3}

Median indoor radon concentration and percentage of houses with indoor radon concentration exceeding $200 \mathrm{~Bq} / \mathrm{m}^{3}$ and $400 \mathrm{~Bq} / \mathrm{m}^{3}$, for different preventive measures [32].

\begin{tabular}{|c|c|c|c|c|}
\hline Preventive measure & Number & $\begin{array}{l}\text { Median } \\
\left(\mathrm{Bq} / \mathrm{m}^{3}\right)\end{array}$ & $\begin{array}{l}\text { Percentage } \\
\text { exceeding } \\
\left(200 \mathrm{~Bq} / \mathrm{m}^{3}\right)\end{array}$ & $\begin{array}{l}\text { Percentage } \\
\text { exceeding } \\
\left(400 \mathrm{~Bq} / \mathrm{m}^{3}\right)\end{array}$ \\
\hline $\begin{array}{l}\text { Sealing of leakages in } \\
\text { substructure, slab-on-grade }\end{array}$ & 31 & 138 & 32 & 10 \\
\hline $\begin{array}{l}\text { Slab-on-grade, sealing work, } \\
\text { sub-slab piping, no fan }\end{array}$ & 58 & 155 & 34 & 10 \\
\hline $\begin{array}{l}\text { Slab-on-grade, sub-slab piping, } \\
\text { no fan }\end{array}$ & 141 & 220 & 55 & 26 \\
\hline $\begin{array}{l}\text { Slab-on-grade, sub-slab piping, } \\
\text { fan operating }\end{array}$ & 21 & 55 & 19 & 10 \\
\hline Crawl-space & 20 & 70 & 10 & 5 \\
\hline Edge-thickened slab & 4 & 66 & 0 & 0 \\
\hline
\end{tabular}

(2) upon completion, test all new properties for radon using NRPB protocols;

(3) remediate properties above the action level by installing a sump and fan; and

(4) re-test these properties to verify that they are below the action level and require no additional remediation.

In another study, the same authors [40] analysed the costeffectiveness of several regulatory regimes (Table 4) when

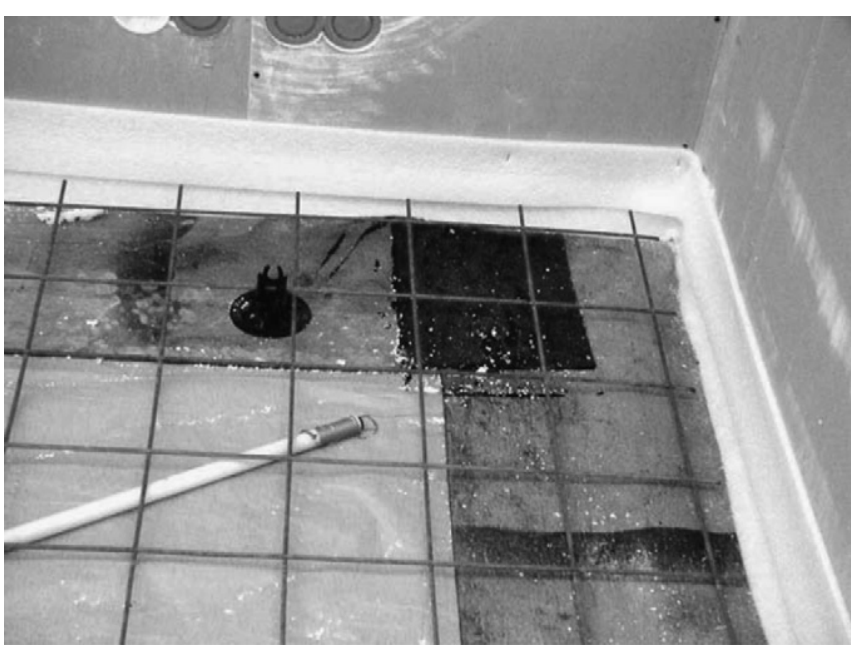

Fig. 3. Bitumen felt installed to the joint of foundation wall and floor slab before casting of the floor [34]. 
a

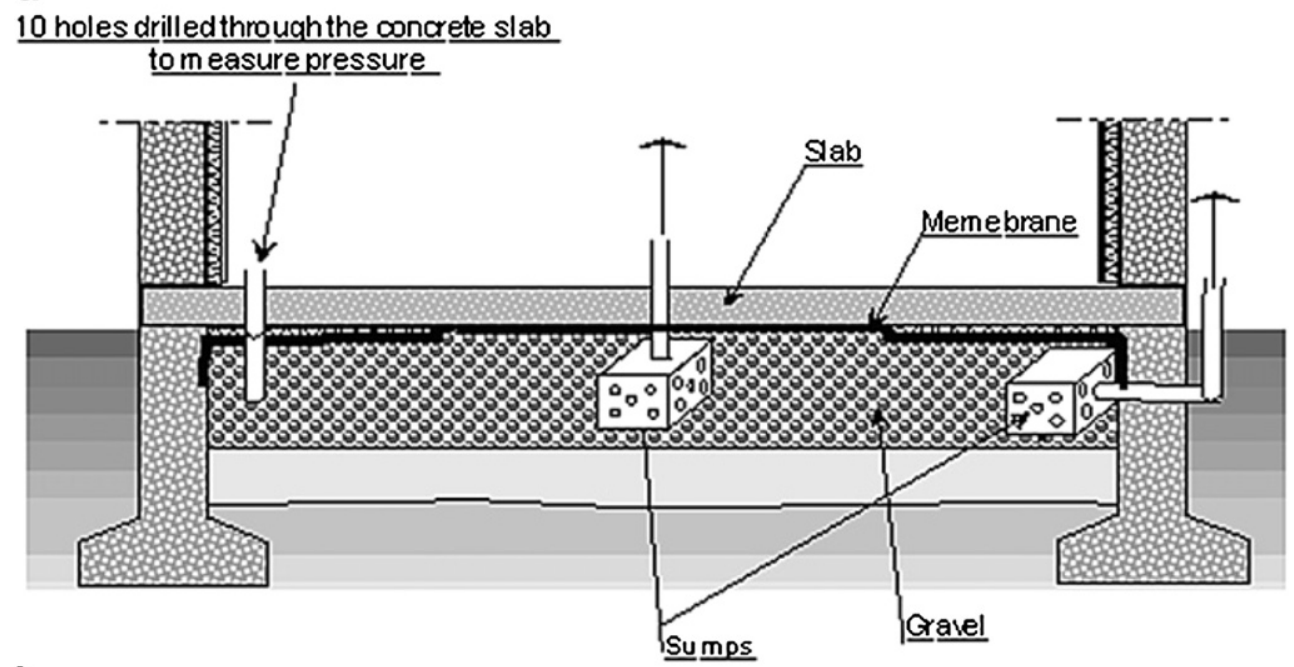

b

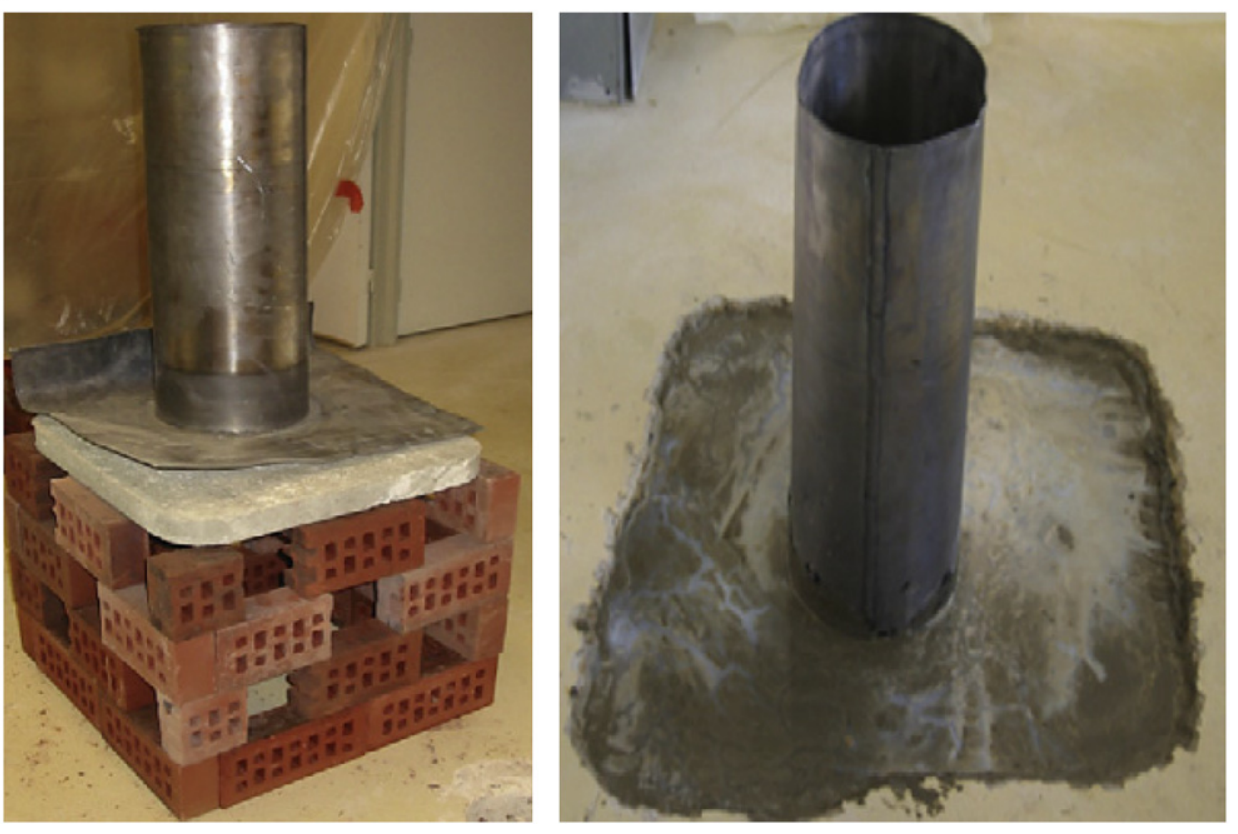

Fig. 4. Soil depressurisation system (SDS): (a) squematics; (b) photos [36].

compared to the UK current regimes [28,29] already described in the beginning of Section 3. The study showed that all alternative regimes performed acceptably against standard criteria for assessing cost-effectiveness, contrary to the current regime, in which cost-effectiveness remained in doubt. Denman et al. [41] used the European Community Radon Software (ECRS) that permits calculation of individual, rather than population-average risk, to analyse the health benefits accruing from a domestic radon remediation program. The results showed that health benefits accruing from remediation were three times lower than expected thus confirming that UK current regulations are not very effective in targeting the groups most at risk. These groups include smokers and families with larger numbers of children. Another similar study [42] concerning the health benefits analysed before and after successful remediation using the sump and pump method showed that they range from $7 \%$ to $11 \%$ less than that expected. These authors mention that radon emanation from building materials sets a baseline level below which radon levels cannot be reduced by sub-slab depressurisation; for the area analysed this threshold falls in the range $50-70 \mathrm{~Bq} / \mathrm{m}^{3}$.

\section{Radon from building materials}

\subsection{Masonry and decorative materials}

Until very recently it was generally accepted that only $5 \%$ of the indoor radon concentration was due to building materials [43]. This is why for a long time, the scientific community has not dedicated a lot of research efforts on this issue. Radioactivity in building materials has been included in the Construction Products Directive [44] but this has still not led to any corresponding standards being adopted by the European Committee for Standardisation. Recently, a the final proposal Directive COM 593 [13], that lays down basic safety standards for protection against the dangers arising from exposure to ionising radiation has been disclosed. This proposal mentions a 2-year deadline in order for 
Table 4

Regulatory regimes [40].

\begin{tabular}{|c|c|}
\hline Regime & Key elements \\
\hline Option A & $\begin{array}{l}\text { - Install membrane as under the current regulations } \\
\text { - Test for radon after property built and buyer in possession } \\
\text { - Remediate property, if needed, by installing sump and fan } \\
\text { - Test to ensure property is below action level }\end{array}$ \\
\hline Option B & $\begin{array}{l}\text { - Install membrane as under the current regulations } \\
\text { - Install sump at time of construction } \\
\text { - Test for radon after property built and buyer in possession } \\
\text { - Fit fan to sump if test reading above action level } \\
\text { - Test further to ensure reading below action level }\end{array}$ \\
\hline Option C & $\begin{array}{l}\text { - Install sump only at the time of construction } \\
\text { - Test for radon after property built and buyer in possession } \\
\text { - Fit fan to sump if test reading above action level } \\
\text { - Test further to ensure reading below action level }\end{array}$ \\
\hline Option & $\begin{array}{l}\text { - No action during construction } \\
\text { - Test for radon after property built and buyer in possession } \\
\text { - Remediate property, if needed, by installing sump and fan } \\
\text { - Test further to ensure reading below action level }\end{array}$ \\
\hline Option E & $\begin{array}{l}\text { - Install membranes during construction of properties } \\
\text { - Install sump when more than } 10 \% \text { of properties above action level } \\
\text { - No testing of property after construction }\end{array}$ \\
\hline
\end{tabular}

the member states to make the transposition of the new Directive into national law. Several authors [45] state that the majority of granitic rocks have low radon exhalation rates. Other authors [46] mention that houses with granitic floor tiles have a higher indoor radon concentration when compared to houses without this kind of floor, however, they also mention that the radon concentration is not much higher than anthropogenic radon emissions. Chen et al. [47] analysed 33 different types of granites and mentioned that only two of them had exhalation rates above $200\left(\mathrm{~Bq} / \mathrm{m}^{2} \mathrm{~d}\right)$. These findings were confirmed by others [45]. These authors studied the combined influence of indoor air ventilation rate and granites exhalation rates serving as floor materials, concluding that the highest exhalation rate granite serving as floor material in a place with a low ventilation rate $(\mathrm{ACH}=0.3)$ contributes only with $18\left(\mathrm{~Bq} / \mathrm{m}^{3}\right)$ to the total concentration (Table 5). However, to $\mathrm{ACH}$ levels near zero, high exhalation rate granite can effectively be responsible for toxic radioactive concentrations. According to these authors the radon concentration due to radon exhalation rate is given by:

$C=\frac{E \cdot A}{\left(\lambda_{0}+\lambda_{\mathrm{V}}\right) V}$

where $E$ is the radon exhalation rate $\left(\mathrm{Bq} / \mathrm{m}^{2} / \mathrm{d}\right)$ of the material installed, $A$ the area $\left(\mathrm{m}^{2}\right)$ of the material exhaling radon, $V$ the air volume $\left(\mathrm{m}^{3}\right)$ of the room, i.e. the room volume minus the volume occupied by room contents, $\lambda_{0}$ is the radon decay constant $(0.181 / \mathrm{d})$ and $\lambda_{\mathrm{v}}$ the air removal rate due to ventilation. Other authors [48] analysed the radon exhalation rate of several Brazilian granites concluding that $91 \%$ can be used inside homes without any concern in respect to health issues. They based their conclusions on the fact that $91 \%$ of the granites were responsible for an indoor concentration below $300 \mathrm{~Bq} / \mathrm{m}^{3}$ for low ventilation conditions and $100 \mathrm{~Bq} / \mathrm{m}^{3}$ for good ventilation conditions. These conclusions seem to forget that recent epidemiological findings demonstrate a lung cancer risk from exposure to indoor radon at levels of the order of $100 \mathrm{~Bq} / \mathrm{m}^{3}$. The radon exhalation rate is influenced, not only by the content of radionuclides but also by the physical properties of the granites [49-51]. Marochi et al. [52] mentioned that the radon exhalation rate is influenced by the granite porosity and that higher porosity is associated with a higher exhalation rate. Other authors [53] reported that specimens in a dry conditions show an exhalation rate $2-5$ times lower when compared to specimens with just
Table 5

Radom concentration $\left(\mathrm{Bq} / \mathrm{m}^{3}\right)$ due to radon exhalation from floor material according to the ventilation rate [47].

\begin{tabular}{llllrr}
\hline Radon exhalation rate $\left(\mathrm{Bq} / \mathrm{m}^{2} \mathrm{~d}\right)$ & \multicolumn{6}{l}{ Air changes per hour $(\mathrm{ACH})$} \\
\cline { 2 - 7 } & 3 & 1 & 0.3 & 0.15 & \multicolumn{1}{c}{0} \\
\hline 5 & 0.03 & 0.09 & 0.3 & 0.6 & 5 \\
10 & 0.06 & 0.2 & 0.6 & 1.2 & 25 \\
50 & 0.3 & 0.9 & 3.0 & 5.9 & 123 \\
100 & 0.6 & 1.8 & 6.0 & 12 & 246 \\
300 & 1.8 & 5.5 & 18 & 35 & 737 \\
\hline
\end{tabular}

$1 \%$ of absorbed water. Allen et al. [54] studied the exhalation rate of granite countertops reporting a higher dispersion. These authors mention that the use of small granite specimens does not allow for extrapolations concerning the exhalation rate of the countertops. Other studies [55] criticize previous estimations on radon exhalation rate made on construction materials specimens, because they under evaluate, by as much as 7 times, the exhalation rate of the material when used in a wall. Results are influenced by the size of the specimens and also by the wall thickness. These authors present a new model to help predict the wall exhalation rate. According to Sahoo et al. the solution of 1-D radon diffusion equation is commonly used to determine radon flux from building surfaces (such as walls and ceiling). However, one limitation in the 1-D solution is the requirement of several input parameters such as radium content, density, and emanation factor and diffusion length of radon in building materials which are not easy to measure. The new model is based on the analytical solution to 3-D radon diffusion equation applicable to a building material system and can be applied to any arbitrary wall thickness irrespective of sample size and any value of radon diffusion length in the building material.

In order to maintain a high quality level of radon measurements periodical calibration is deemed necessary [56]. Collignan et al. [57] reported the use of an AlphaGUARD monitor was first calibrated by the Institut de Radioprotection et de Sûreté Nucléaire IRSN. For the determination of radon gas concentration other authors Abdallah et al. [58] used a monitor consisting of an aluminium sphere which incorporates a surface barrier detector isolated in a PVC-mounting. The monitor calibration has been carried out by introducing a known amount of radon into the sphere. From several calibrations, the average value of the detection efficiency was $720 \mathrm{~Bq}$, which was fairly independent of the flow rate. At $1 \mathrm{~h}$ counting time interval the sensitivity for radon was $1.1 \mathrm{mBq} / \mathrm{L}$. Other authors [59] made intercomparisons of two types of passive ${ }^{222} \mathrm{Rn}-{ }^{220} \mathrm{Rn}$ detectors (commercially available as Raduet and Radopot detectors), developed by the National Institute of Radiological Sciences, Japan (NIRS), using the Physikalisch Technische Bundesanstalt, Germany (PTB) ${ }^{222}$ Rn chamber. The experimental uncertainties as the relative standard deviation ranged from $2 \%$ to $8 \%$ for the Raduet detectors and $5-13 \%$ for Radopot detectors in ${ }^{222} \mathrm{Rn}$ concentration at each activity level.

\subsection{Other construction materials}

It is believed that, in general, construction materials do not show alarming radioactivity levels [60,61]. The same, however, cannot be said about some industrial by-products used for concrete production such as some kind of blast furnace slags and some fly ashes (Table 6). Since mineral coal contains radionuclides, this means that the fly ashes produced in thermal power plants must be analysed regarding this parameter [64]. Some studies [65,66] show that concrete with $60 \%$ cement replacement by fly ash has a radon concentration which is 2 times higher when compared to control 
Table 6

Typical and maximum activity concentrations in common building materials and industrial by-products used for building materials in Europe $[62,63]$.

\begin{tabular}{|c|c|c|c|c|c|c|}
\hline \multirow[t]{2}{*}{ Material } & \multicolumn{3}{|c|}{$\begin{array}{l}\text { Typical activity } \\
\text { concentration }(\mathrm{Bq} / \mathrm{kg})\end{array}$} & \multicolumn{3}{|c|}{$\begin{array}{l}\text { Maximum activity } \\
\text { concentration }(\mathrm{Bq} / \mathrm{kg})\end{array}$} \\
\hline & ${ }^{226} \mathrm{Ra}$ & ${ }^{232} \mathrm{Th}$ & ${ }^{40} \mathrm{~K}$ & ${ }^{226} \mathrm{Ra}$ & ${ }^{232} \mathrm{Th}$ & ${ }^{40} \mathrm{~K}$ \\
\hline \multicolumn{7}{|l|}{ Construction materials } \\
\hline Concrete & 40 & 30 & 400 & 240 & 190 & 1600 \\
\hline Light-weight concrete & 60 & 40 & 430 & 2600 & 190 & 1600 \\
\hline Ceramic bricks & 50 & 50 & 670 & 200 & 200 & 2000 \\
\hline Concrete blocks & 10 & 10 & 330 & 25 & 30 & 700 \\
\hline Natural stone & 60 & 60 & 640 & 500 & 310 & 4000 \\
\hline Natural gypsum & 10 & 10 & 80 & 70 & 100 & 200 \\
\hline \multicolumn{7}{|l|}{ Industrial by-products } \\
\hline Phosphogypsum & 390 & 20 & 60 & 1100 & 160 & 300 \\
\hline Blast furnace slag & 270 & 70 & 240 & 2100 & 340 & 1000 \\
\hline Coal fly ash & 180 & 100 & 650 & 1100 & 300 & 1500 \\
\hline
\end{tabular}

concrete. However, there's not a direct correlation between the concentration and exhalation rates because this parameter is also influenced by the concrete internal structure. Thus meaning that it is possible to have a concrete with a lower concentration but with a more porous structure and therefore with a higher exhalation rate [67]. Taylor-Lange et al. [68] show that concrete floors made with $25 \mathrm{wt} \%$ fly ash resulted in $90 \%$ of the simulated homes having a double the dose compared to the control concrete $\left(2.3 \mathrm{~Bq} / \mathrm{m}^{3}\right)$. This is not only a problem for new buildings but also in the refurbishment context that often includes the replacement of wood floors by concrete based slabs. Recent studies [69] based on 2727 concrete specimens from 23 European countries show very different radon concentrations and some as high as $1450 \mathrm{~Bq} / \mathrm{kg}$ for the radionuclide ${ }^{40} \mathrm{~K}$ in Portugal, thus meaning that some countries should have a special attention to this subject.

\section{Conclusions}

Radon constitutes the second cause of lung cancer in the general population, the first being smoking. In the past, it was accepted that only radon concentrations above $400 \mathrm{~Bq} / \mathrm{m}^{3}$ could constitute a health risk, however, recent epidemiological findings demonstrate lung cancer risk from exposure to indoor radon at levels in the order of $100 \mathrm{~Bq} / \mathrm{m}^{3}$. It is estimated that millions of residents in Europe live in homes which have radon concentrations above $200 \mathrm{~Bq} / \mathrm{m}^{3}$ however; the majority of the public seems to consider the health risks involved from exposure to radon as being negligible. Still recent regulation continues to allow high indoor radon concentrations. The recent agenda on building energy efficiency refurbishment can provide the right context in order to raise the radon problem once again. Using post-construction remediation like soil depressurisation systems seems to be more cost-effective than the use of protection measures installed during construction like radon-barrier membranes which have a significant failure rate. Several investigations have attempted to estimate the contribution of building materials to the indoor radon concentration, however, while some used very small specimens the others used specimens with different water content which prevents comparisons between the different studies. Some authors criticize previous estimations on radon exhalation rate made on construction materials specimens, because they under evaluate, by as much as 7 times, the exhalation rate of the material when used in a wall. This shows how much the radon still needs further investigations in order to have a clear picture of the real contribution of masonry and decorative materials to indoor radon concentration.

\section{References}

[1] Pacheco-Torgal F, Jalali S. Toxicity of building materials. A key issue in sustainable construction. Int J Sustain Eng Taylor Francis 2011;4:281-7.

[2] Clement $\mathrm{CH}$. Assessment of the detriment from exposure to radon and its progeny. Ann ICRP 2010;40(1):41-7.

[3] WHO. WHO handbook on indoor radon: a public health perspective. Geneva 27, Switzerland: World Health Organization; 2009.

[4] Field RW, Duport PJ, Hendee WR. Exposure to residential radon causes lung cancer. Med Phys 2003;30(4):485-8.

[5] Chauhan V, Howland M, Mendenhall A, O'Hara S, Stocki TJ, McNamee JP, et al Effects of alpha particle radiation on gene expression in human pulmonary epithelial cells. Int J Hyg Environ Health 2012;215(5):522-35.

[6] Veloso B, Nogueira JR, Cardoso MF. Lung cancer and indoor radon exposure in the north of Portugal - an ecological study. Cancer Epidemiol 2012;36(1):e26-32.

[7] Bräuner EV, Andersen CE, Andersen HP, Gravesen P, Lind M, Ulbak K, et al. Is there any interaction between domestic radon exposure and air pollution from traffic in relation to childhood leukemia risk? Cancer Causes Control 2010;21(11):1961-4.

[8] Barros-Dios JM, Ruano-Ravina A, Pérez-Ríos M, Castro-Bernárdez M, AbalArca J, Tojo-Castro M. Residential radon exposure, histologic types, and lung cancer risk. A case-control study in Galicia, Spain. Cancer Epidemiol Biomark Prev 2012;21(6):951-8.

[9] Sethi TK, El-Ghamry MN, Kloecker GH. Radon and lung cancer. Clin Adv Hematol Oncol 2012;10(3):157-64.

[10] Wheeler BW, Allen J, Depledge MH, Curnow A. Radon and skin cancer in southwest England: an ecologic study. Epidemiology 2012;23(1):44-52.

[11] Dinua A, Cosma C, Sainz C, Poncelab L, Vasiliniuc S. Lung cancer attributable to indoor radon exposures in two radon - Prone areas, Stei (Romania) and Torrelodones (Spain). Physics Conference, TIM-08; Timisoara, Romania. AIP Conf Proc 2009;1131:175-80.

[12] Krewski D, Lubin J, Zielinski J, Alavanja M, Catalan V, Field R, et al. A combined analysis of North American case-control studies of residential radon and lung cancer. J Toxicol Environ Health A 2006;69:533-97.

[13] COM. 593-Proposal for a council directive laying down basic safety standards for protection against the dangers arising from exposure to ionising radiation; 2011.

[14] Jelle B. Development of a model for radon concentration in indoor air. Sci Total Environ 2012:416:343-50.

[15] Bradley EJ, Lomas PR, Green BMR, Smithard J. Radon in dwellings in England: 1997 review. National Radiological Protection Board Report (NRPB) R293. Chilton, Oxon.

[16] Ryan D, Kelleher CC. A survey of householders'mitigation strategy. Eur J Public Health 1999;9(1):62-4.

[17] Phillips PS, Fraser JD, Denman AR. Effectiveness of secondary radon protection in Northamptonshire houses. Environ Manag Health 2000;11(4):337-52.

[18] Denman A, Groves-Kirkby C, Coskeran T, Parkinson S, Phillips P, Torneberg R. Evaluating the health benefits and cost-effectiveness of the radon remediation programme in domestic properties in Northamptonshire, UK. Health Policy 2005b;73:139-50.

[19] European Union. Directive 2002/91/EC of the European Parliament and of the Council of December 16th, 2002 on the energy performance of buildings. Official J Eur Communities January 4th.

[20] European Union. Directive 2010/31/EU of the European Parliament and of the Council of May 19th, 2010 on the energy performance of buildings (recast) Official J Eur Union 18 June, 2010.

[21] Xing Y, Hewitt N, Griffiths P. Zero carbon buildings refurbishment--a hierarchical pathway. Renew Sust Energ Rev 2011;15:3229-36.

[22] Power A. Does demolition or refurbishment of old and inefficient homes help to increase our environmental, social and economic viability? Energy Policy 2008;36:4487-501.

[23] Synnott H, Fenton D. An evaluation of radon reference levels and radon measurement techniques and protocols in European countries; 2005b. European Radon Research and Industry Collaborative Concerted Action (ERRICCA2), European Commission Contract (FIRI-CT-2001-20142).

[24] International Commission on Radiological Protection. Recommendations of the ICRP. ICRP Publication; 2008. 103.

[25] NRPB; 2008. National Radiological Protection Board (NRPB). Statement on human exposure to radon in homes. Doc NRPB 1990; 1(1):17-32.

[26] Bochicchio F. The newest international trend about regulation of indoor radon. Radiat Prot Dosimetry 2011;146:2-5.

[27] Holmgren O, Arvela H. Assessment of current techniques used for reduction of indoor radon concentration in existing and new houses in European countries. STUK, A251. Helsinki, Finland: Radiation and Nuclear Safety AuthoritySTUK; 2012.

[28] UK: NRPB; 1997. BRE (Building Research Establishment). Radon: guidance on protective measures for new dwellings 1999 edition. BRE report BR211. Garston, Herts, UK: BRE; 1999.

[29] Environmental Radon Newsletter. Health Protection Agency Board gives advice on radon measures for new homes, vol. 56(1), Chilton, Oxon, UK Autumn 2008.

[30] Synnott H, Pollard D, Colgan P, Fenton D, A survey of the impact of amending building regulations on radon concentrations in Irish homes. In: Proc 11th Congress of the International Radiation Association (IRPA11) Madrid; 2004. 
[31] Denman AR, Phillips PS, Groves-Kirkby CJ, Crockett RM, Do radon-proof membranes reduce radon levels adequately in new houses? In: Proceedings of the seventh SRP International Symposium; Cardiff, 12-17; 2005.

[32] Scivyer C. Radon protection for new buildings: a practical solution from the UK. Sci Total Environ 2001;272:91-6.

[33] Arvela H. Experiences in radon-safe building in Finland. Sci Total Environ 2001;272:169-74.

[34] Arvela H, Bergman J, Yrjölä R, Kurnitski J, Matilainen M, Järvinen P. Developments in radon-safe building in Finland. Radioact Environ 2005;7.

[35] Groves-Kirkby C, Denman A, Phillips P, Crockett R, Woolridge A, Tornberg R. Radon mitigation in domestic properties and its health implications-a comparison between during-construction and post-construction radon reduction. Environ Int 2006;32:435-43.

[36] Abdelouhab M, Collignan B, Allard F. Experimental study on passive soil depressurisation system to prevent soil gaseous pollutants into building. Build Environ 2010;45:2400-6.

[37] Coskeran T, Denman A, Phillips P, Gillmore G. A critical comparison of the cost-effectiveness of domestic radon remediation programmes in three counties of England. J Environ Radioact 2002;62:129-44.

[38] Garber A, Phelps C. Economic foundations of cost-effectiveness analysis. J Health Econ 1997; 16:1-31.

[39] Coskeran T, Denman A, Phillips P, Tornberg R. A cost-effectiveness analysis of radon protection methods in domestic properties: a comparative case study in Brixworth, Northamptonshire, UK. J Environ Radioact 2006;91:73-89.

[40] Coskeran T, Denman A, Phillips P, Tornberg R. A critical evaluation of the costeffectiveness of radon protection methods in new homes in a radon affected area of England. Environ Int 2009;35:943-51.

[41] Denman A, Phillips P, Torneberg R, Groves-Kirkby C. Analysis of the individual health benefits accruing from a domestic radon remediation programme. J Environ Radioact 2005;79:7-23.

[42] Denman A, Briggs D, Allison C, Groves-Kirkby C, Phillips P, Crockett R. A detailed evaluation of the individual health benefits arising in a domestic property following radon remediation e a case-study in Northamptonshire, U.K. J Environ Radioact 2008;99:1175-84.

[43] Lao K. Controlling indoor radon. New York: Van Nostrand Reinhold; 1990

[44] Pacheco-Torgal F, Jalali S, Fucic A. Toxicity of building materials. Cambridge: Woodhead Publishing Limited; 2012. 480 p.

[45] Pavlidou S, Koroneos A, Papastefanou C, Christofides G, Stoulos S, Vavelides M. Natural radioactivity of granites as building materials. J Environ Radioact 2006;89:48-60.

[46] Fokianos K, Sarrou I, Pashalidis I. Increased radiation exposure by granite used as natural tiling rock in Cypriot houses. Radiat Meas 2007;42:446-8.

[47] Chen J, Rahman N, Atiya I. Radon exhalation from building materials for decorative use. J Environ Radioact 2010:101:317-22.

[48] Anjos R, Ayub J, Cid A, Cardoso R, Lacerda T. External gamma-ray dose rate and radon concentration in indoor environments covered with Brazilian granites. J Environ Radioact 2011;102:1055-61.

[49] Tuccimei P. Moroni M, Norcia D. Simultaneous determination of ${ }^{222} \mathrm{Rn}$ and ${ }^{220} \mathrm{Rn}$ exhalation rates from building materials used in Central Italy with accumulation chambers and a continuous solid state alpha detector: influence of particle size, humidity and precursors concentration. Appl Radiat Isot 2006; 64:254-63.

[50] Shweikani R, Raja G. Radon exhalation from some finishing materials frequently used in Syria. Radiat Meas 2009;44:1019-23.
[51] Ujic P, Celikovic I, Kandic A, Vukanac I, Durasevic M, Dragosavac D, et al. Internal exposure from building materials exhaling $222^{\mathrm{Rn}}$ and $220^{\mathrm{Rn}}$ as compared to external exposure due to their natural radioactivity content. Appl Radiat Isot 2010;68:201-6.

[52] Marocchi M, Righi S, Bargossi G, Gasparotto G. Natural radionuclides content and radiological hazard of commercial ornamental stones: an integrated radiometric and mineralogical-petrographic study. Radiat Meas 2011;46: 538-45.

[53] Hassan NM, Ishikawa T, Hosoda M, Iwaoka K, Sorimachi A, Sahoo SK, et al. The effect of water content on the radon emanation coefficient for some building materials used in Japan. Radiat Meas 2011;46:232-7.

[54] Allen J, Minegishi T, Myatt T, Stewart J, McCarthy J, MacIntosh D. Assessing exposure to granite countertops part 2: radon. J Expo Sci Environ Epidemiol 2010;20:263-72.

[55] Sahoo B, Sapra B, Gaware J, Kanse S, Mayya Y. A model to predict radon exhalation from walls to indoor air based on the exhalation from building material samples. Sci Total Environ 2011;409:2635-41.

[56] Gennaro V. Development of calibration techniques for active and passive radon detectors. In: PhD in Fundamental and Applied Phisics, University of Naples; 2007.

[57] Collignan B, Lorkowski C, Améon R. Development of a methodology to characterize radon entry in dwellings. Build Environ 2012;57(2012):176-83.

[58] Abdallah A, Mohery M, Yaghmour S, Alddin S. Radon exhalation and natural radiation exposure in low ventilated rooms. Radiat Phys Chem 2012;81(11): 1710-4.

[59] Sorimachi A, Ishikawa T, Tokonami S. Performance test for radon measuring instruments using radon chamber at PTB. Appl Radiat Isot 2012;10:994-8.

[60] Papaefthmiou $\mathrm{H}$, Gouseti O. Natural radioactivity and associated radiation hazards in building materials used in Peloponnese, Greece. Radiat Meas 2008; 43:1453-7.

[61] Damla N, Cevik U, Kobya A, Celik A, Celik N, Yıldırım I. Assessment of natural radioactivity and mass attenuation coefficients of brick and roofing tile used in Turkey. Radiat Meas 2011;46:701-8.

[62] Kovler K. Haquin G, Manasherov V, Neman E, Lavi N. Natural radionuclides in building materials available in Israel. Build Environ 2002;37:531-7.

[63] Kovler K. Radiological constraints of using building materials and industrial by-products in construction. Constr Build Mater 2009;23:246-53.

[64] Mahur A, Kumar R, Mishra M, Sengupta D, Prasad R. An investigation of radon exhalation rate and estimation of radiation doses in coal and fly ash samples. Appl Radiat Isot 2008;66:401-6.

[65] Kovler K, Perevalov A, Steiner V, Metzger L. Radon exhalation of cementitious materials made with coal fly ash: part 1-scientific background and testing of the cement and fly ash emanation. J Environ Radioact 2005;82: 321-34.

[66] Kovler K, Perevalov A, Steiner V, Metzger L. Radon exhalation of cementitious materials made with coal fly ash: part 2-testing hardened cement fly ash pastes. J Environ Radioact 2005;82:335-50.

[67] Keller G, Hoffmann B, Feigenspan T. Radon permeability and radon exhalation of building materials. Sci Total Environ 2001;272:85-9.

[68] Taylor-Lange S, Stewart J, Juenger M, Siegel J. The contribution of fly ash toward indoor radon pollution from concrete. Build Environ 2012;56:276-82.

[69] Trevisi R, Risica S, D’Alessandro M, Paradiso D, Nuccetelli C. Natural radioactivity in building materials in the European Union: a database and an estimate of radiological significance. J Environ Radioact 2012;105:11-20. 